\title{
Chapter 2 \\ Environmental Settings and Their Changes in the Last Decades
}

\author{
Nicole Wellbrock, Nadine Eickenscheidt, Erik Grüneberg, \\ and Rebekka Bögelein
}

\subsection{Introduction}

The historical use of European forests has significantly affected forest soil conditions (Wittich 1951; Härdtle 1995; Ludemann 2002; Lüst and Giani 2006; Peters 1990; Rinklebe and Makeschin 2003). As a consequence of centuries of use by humans, until recently forests have been subject to severe losses of nutrients, for example, through harvesting of wood for fuel and lumber, bark utilization and litter raking, forest pasturing, clear cutting and slash-and-burn clearance with subsequent agricultural use and the associated erosion of the soils (Ellenberg and Leuschner 2010; Kreutzer 1972). Today, standard restrictions on forest utilization to timber harvesting have meant that these impacts have been curbed significantly (Bundeswaldgesetz). The majority of modern forests are the result of decisions based on silvicultural management that has left behind stands of multiple generations. The selection and mix of tree species and the structure of the forest stands have had a particularly significant impact (Augusto et al. 2002; Pretzsch et al. 2010). Forest management has exerted a considerable influence on the quantity and distribution of organic substances in the soils, the material cycles, deposition loading and the acid-base ratio, as well as the interior forest climate and water regime.

Over the past decades, inputs from atmospheric pollution caused by humans have had a significant impact on forests (Ellenberg 1971; Ulrich 1987; de Vries et al.

\footnotetext{
N. Wellbrock $(\triangle) \cdot$ E. Grüneberg $\cdot$ R. Bögelein

Thünen Institute of Forest Ecosystems, Eberswalde, Germany

e-mail: nicole.wellbrock@thuenen.de; erik.grueneberg@thuenen.de; rebekka.boegelein@gmx. de

N. Eickenscheidt

Thünen Institute of Forest Ecosystems, Eberswalde, Germany
}

State Agency for Nature, Environment and Consumer Protection of North Rhine-Westphalia,

Recklinghausen, Germany

e-mail: nadine.eickenscheidt@lanuv.nrw.de 
2014; Waldner et al. 2015). At the end of the 1970s and in the early 1980s, this was first officially identified based on the condition of the crowns of the trees and was initially discussed as "forest dieback" and later as a new type of forest damage in many countries (Kauppi et al. 1990; Ulrich 1983). The three main effects of air pollution from sulphur $(\mathrm{S})$ and nitrogen $(\mathrm{N})$ compounds as well as ozone that were identified and discussed as reasons for this damage were (1) direct harmful effects on the assimilation organs of trees from acidic S emissions (Wentzel 1979, 1982) and ozone (Bucher 1984); (2) root damage and magnesium deficiencies resulting from soil acidification, leaching of bases and release of aluminium and heavy metal ions that are toxic to roots (Ulrich 1986, 1995); and (3) nutrient imbalances accruing due to the deposition of eutrophying $\mathrm{N}$ (Nihlgård 1985).

The onset of the industrial revolution has resulted in a continuous increase in anthropogenic depositions of sulphur and nitrogen in Central Europe. These permanent element inputs led to changes in the element budgets of forest ecosystems, which therefore can no longer be considered as constant but as dynamic systems. The acid-base balance and the $\mathrm{N}$ budget are particularly affected by anthropogenic depositions. Atmospheric $\mathrm{S}$ and $\mathrm{N}$ compounds mainly originate from industrial sources such as traffic $\left(\mathrm{NO}_{y}\right)$, industrial plants, energy conversion $\left(\mathrm{SO}_{x}, \mathrm{NO}_{y}\right)$ as well as intensive agriculture $\left(\mathrm{NH}_{x}\right)$. Sulphur dioxide and $\mathrm{NO}_{y}$ form strong acids with the water contained in the atmosphere and are mostly carried to the forest soil by precipitation. The canopy absorbed parts of nitrogen, too. Deposition of $\mathrm{NH}_{x}$ also results in soil acidification due to nitrification to nitrate. Nitrate leaching can further lead to ground water pollution and cation losses. In addition, the greenhouse gas nitrous oxide may be produced during denitrification of nitrate. In natural ecosystems, $\mathrm{N}$ is limiting growth. However, eutrophication of forest ecosystems indicated by nutrient imbalances and changes in the species composition may be results of long-term $\mathrm{N}$ surplus. Besides $\mathrm{S}$ and $\mathrm{N}$ depositions, anthropogenic base cation depositions occur and could in particular be observed as alkaline-rich fly ashes in former eastern Germany. Deposition rates of $\mathrm{S}$ and $\mathrm{N}$ below which no long-term harmful effects on ecosystem structure and function are expected are based on the concept of critical loads (Nilsson and Grennfelt 1988).

The "stress hypothesis" links the effects of the deposition of substances with additional biotic and climatic factors into a complex of interactions among predisposing, triggering and contributing stress factors (Manion 1981; Schütt et al. 1984; Eichhorn et al. 2005). Therefore, the interactive effects of climate change can also be described together with the effects of air pollution and substance depositions; in such a scenario, effects can both be enhanced and mitigated (Bytnerowicz et al. 2007).

Following on the discussion of forest decline in Germany, a nationwide soil condition inventory (National Forest Soils Inventory; NFSI) was launched at the end of the 1980s with surveys taking place at approximately 1900 sampling sites in forests. Systematic inventory sampling in $8 \times 8 \mathrm{~km}$ grids across the country allowed describing forest soil conditions representative for Germany. Combined with intensive monitoring (Level II), the NFSI represents an integral component of environmental monitoring of forest ecosystems. Results of the first National Forest Soils 
Inventory (NFSI I) were published by Wolff and Riek (1996) reporting a substantial and extensive acidification and depletion of basic substances independent of substrate throughout the topsoil layer, as well as a tendency towards levelling of the chemical condition of the topsoil. Accumulation of copper and lead in the organic layer was elevated. The conclusions were supported by critical results for the nutritional status and crown condition of the trees. Elevated depositions of S, N and heavy metals were seen as the cause for the very low contents of magnesium, in particular in spruce trees, which were also evident in higher loss of needles. Transnational action to control air pollution (e.g. Convention of Long-Range Transboundary Air Pollution CLRTAP; UNECE 1979) has meant a decrease of S depositions in particular. Input of fly ash has also dropped significantly since lignite combustion, the principal source of fly ash, has declined considerably following the reunification of Germany and technical efforts (filter systems). In contrast, however, little change has been achieved in inputs of N (Waldner et al. 2014, 2015). Accordingly, atmospheric deposition must continue to be regarded as crucial (Verstraeten et al. 2012). As a consequence raised from the results of the NFSI I, forest stands especially affected by acidification were limed, and several countries began intensive forest conversion efforts.

To describe the changes of forest soil conditions over a period of 15 years, the second National Forest Soils Inventory (NFSI II) was carried out from 2006 to 2008. An integrated evaluation of the forest conditions and their soils was made possible through correlation with other surveys of crown condition, nutritional status of the trees and vegetation. In addition interpolated climate data, information about geology and substrate classes and profile descriptions with soil-type and humus-type classification are available.

\subsection{Changes of Atmospheric Deposition on NFSI Plots}

The modelled atmospheric depositions on NFSI plots show a considerable decline in element inputs during the last two decades (Fig. 2.1) as consequence of extensive emission reduction measures. The importance of $\mathrm{NH}_{x}$ on the total acid deposition however increased due to the strong decrease of S deposition (Schöpp et al. 2003). Therefore, reduced $\mathrm{N}$ inputs from agriculture represent the main source of impact for many forests in Germany in recent years. Specific regional patterns of atmospheric depositions have developed. Spatial differences depend upon the source (e.g. agriculture, traffic infrastructure), the diameter and weight of the particles, the climatic situation and the surface or canopy roughness. 


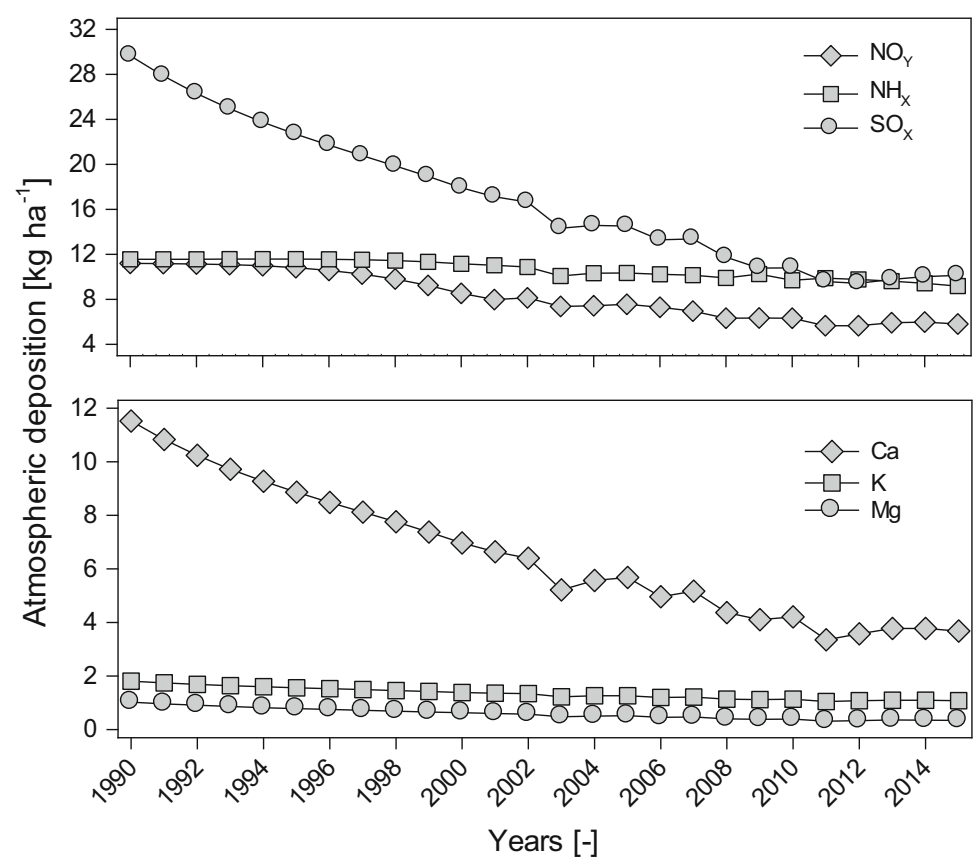

Fig. 2.1 Trends of annual atmospheric depositions of pollutants $\left(\mathrm{SO}_{x}\right.$, oxidized $\mathrm{S} ; \mathrm{NH}_{x}$, reduced $\mathrm{N}$; $\mathrm{NO}_{y}$, oxidized $\mathrm{N}$ ) and base cations $(\mathrm{Ca}, \mathrm{K}, \mathrm{Mg}$ ) between 1990 and 2006. Depositions were sea saltcorrected with exception of $\mathrm{N}$ depositions

\subsection{Climate}

Germany is situated in the warm-temperate humid climate zone of middle latitudes in the transition between oceanic climate of Western Europe and continental climate of Eastern Europe. The oceanic climate impact decreases from West to East, while from North to South, the climate is controlled by increasing height above sea level. The lowlands are characterized by relatively warm and dry climate; however, a cool and humid climate is predominant at the mountain ridges. The slopes of the mountain ranges are characterized by locally limited warm climate because those areas are protected against cool winds due to their lower height. Climate date was derived by a method described by Ziche and Seidling (2010). Evaluating climate variables is based on the evaluation criteria by AK Standortskartierung (2003) as well as revaluations by Wolff et al. (2003). The annual mean temperature on sites of the NFSI ranged between 7 and $9{ }^{\circ} \mathrm{C}$. The distribution of annual mean temperature showed with $1 \%$ a very small proportion of alpine but with $44 \%$ a high proportion of colline sites. Also frequently were submontane sites accounting for $29 \%$, while montane and planare sites were less common sharing $12 \%$ and $10 \%$, respectively. The proportion of high-montane and warm-planar sites decreased significantly with a share each of $2 \%$ (Fig. 2.2). 


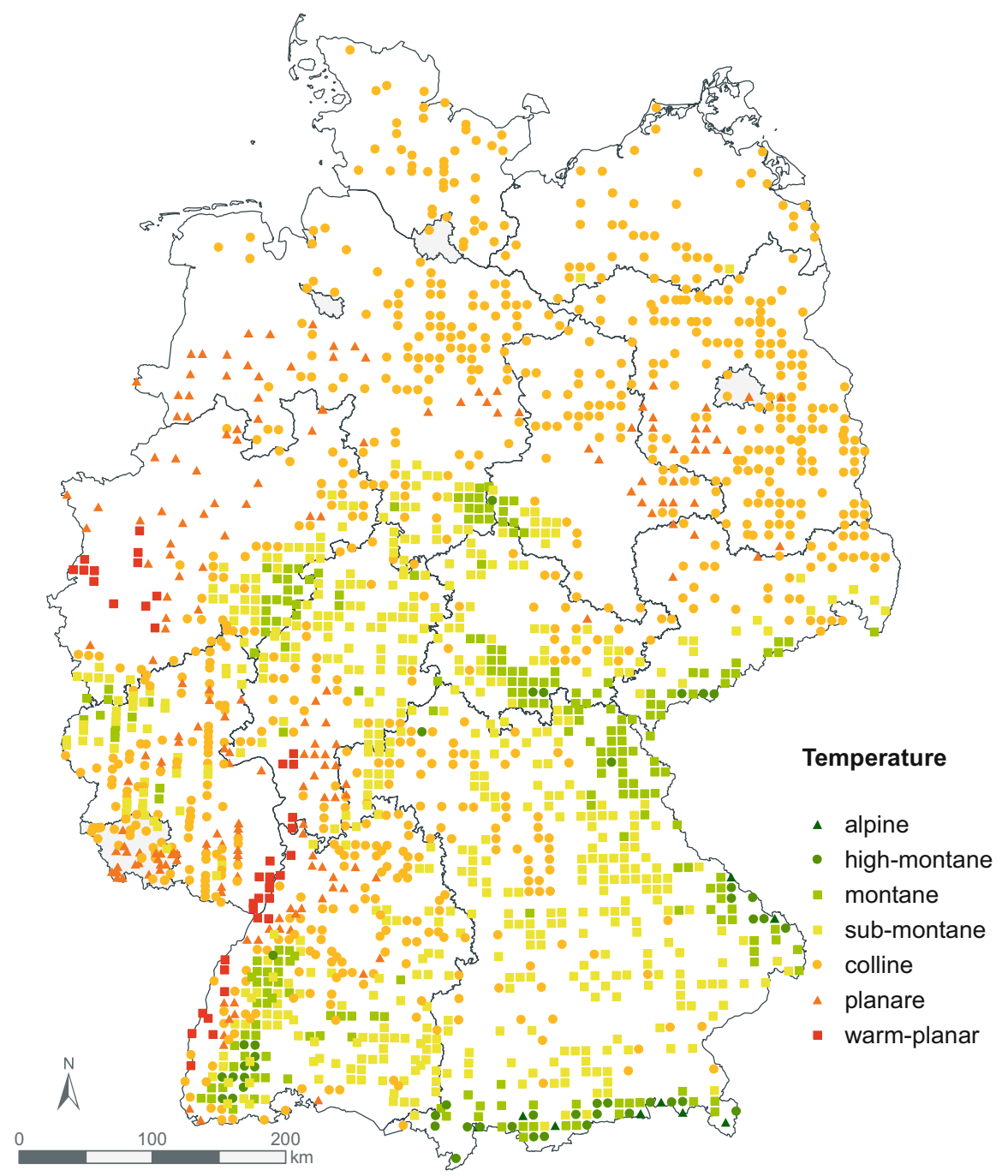

Fig. 2.2 Spatial distribution of the annual mean temperature on NFSI plots (classification according to Wolff et al. 2003)

In case of the annual mean precipitation, there were a proportion of $<0.5 \%$ with only a few very dry sites; however, much more sites were dry (14\%), very weak dry $(14 \%)$, humid (10\%) and very humid (9\%). Sites with moderate precipitation were most frequent ranging from weak dry to weak humid accounting for $25 \%$ and $28 \%$, respectively (Fig. 2.3). 


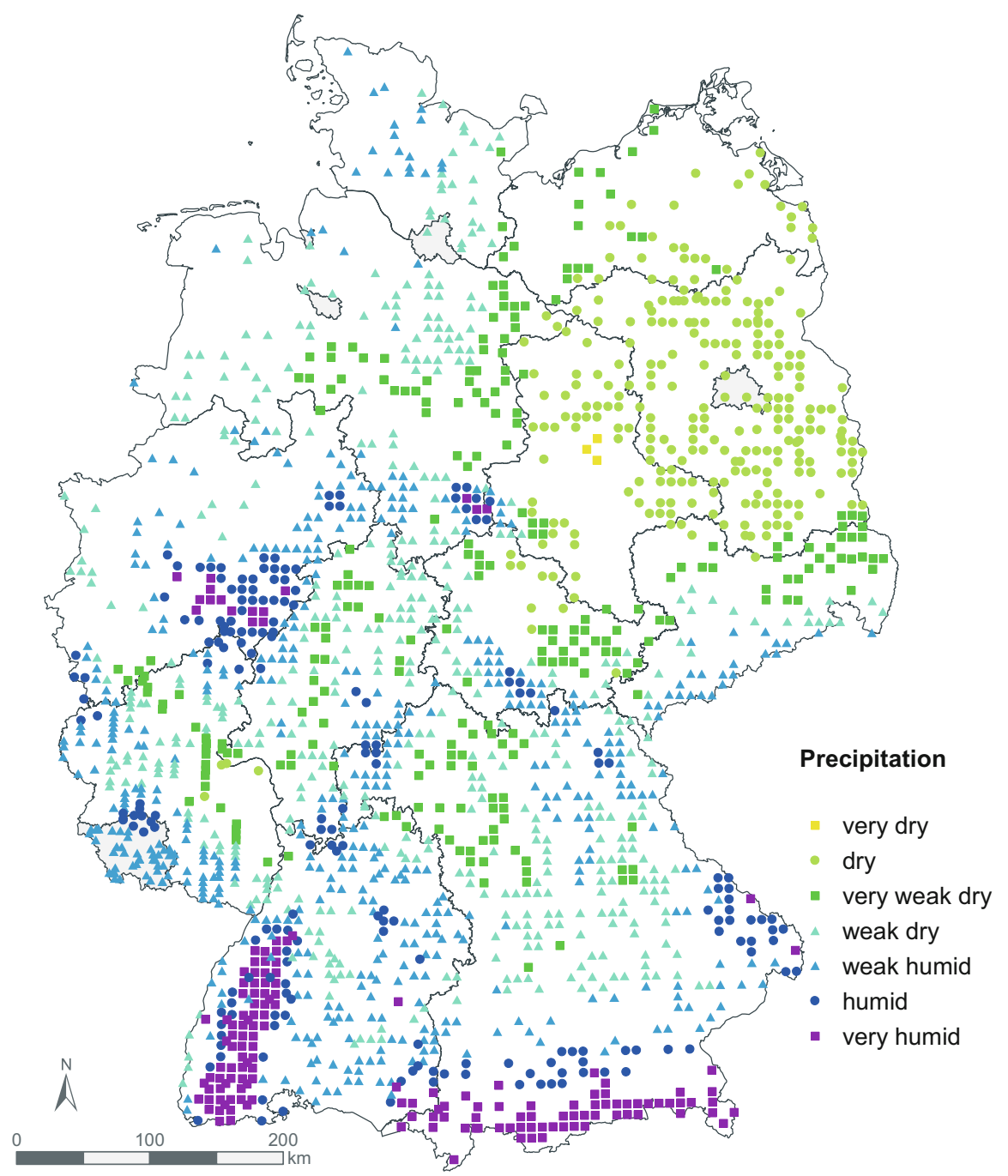

Fig. 2.3 Spatial distribution of the annual precipitation on NFSI plots (classification according to Wolff et al. 2003)

\subsection{Soil Parent Material Groups}

The growth of forest trees is controlled by water availability and nutrition supply which is especially determined by site properties resulting from parent materials for soil formation. We distinguished among eight groups of various soils parent materials. The largest proportion with $42 \%$ was found for soils from base-poor consolidated bedrock, followed by soils from base-poor unconsolidated sediment accounting 
for $21 \%$. The latter group consists of nutrient-poor, largely sandy river deposits, periglacial sediments or river terrace deposits and is widely distributed in the North German Lowlands, while the former group comprises various acidic, crystalline and sedimentary bedrocks, partly covered or mixed with loess. These sites are most frequent in mountain ranges of middle and south Germany. Loamy soils of the lowland accounted for $13 \%$ of the survey plots, covering a broad range of various forest sites. Main distribution areas are the undulating lowlands and hilly areas with loamy-clayey, partly calcareous moraine deposits as well as sites in loess areas. About $9 \%$ of the surveyed plots were soils from weathered carbonate bedrock. Main distribution areas are the continuous mountain range built of carbonate and dolomite bedrock with their weathering products and redeposited material. Soils from basic-intermediate bedrock are small-scale distributed in hilly areas and mountain areas accounting for $8 \%$ of the surveyed plots. Additionally, soils from marlstone and claystone weathering were integrated into this group. Soils of alluvial plains contain sites in broad river valleys, including terraces and lowlands with a proportion of $3 \%$ less frequent. Typical sites comprise of frequently alternating sandy to clayey, partly calcareous fluviatile sediments. Soils from the Alps accounted for $1 \%$ of the surveyed plots. The group integrates sites of different altitudes of the Alps from limestone and dolomite as well as of noncalcareous silicate rocks. Organic soils play with a proportion of $2 \%$ a minor role in the collective. Moreover, soil development and properties as well as chemical response to environmental conditions are different from soils derived from weathered mineral matter.

\subsection{Soil Classes}

Soil classes (suborders) differentiate according to soil dynamics and morphological properties caused by specific dominant pedological processes. For each of the surveyed plots soil classes could be designated by describing soil profiles according to Ad-HocAG_Boden (2005). Brown soils (Cambisol/Arenosols) were the most common soil class accounted for 55\% of all soils and distributed over a wide range of various soil parent materials. Soils with stagnic properties and Podzols are also characterized by a broad spectrum of site variability. These soil classes are common both in the North German Lowlands and hilly areas and mountain ranges of middle and south Germany, whereas soils with stagnic properties accounted for $11 \%$, while Podzols accounted for $7 \%$. Lessives are particularly suitable for cropland; however, they accounted for $8 \%$ of the surveyed plots. The proportion of $\mathrm{Ah} / \mathrm{C}$ soils and steppe soils is similar to the lessives. Nevertheless, this soil class comprises soils that are very different in physical and chemical properties. Terra calcis and pelosols amounted to a proportion of $3 \%$ and $1 \%$, respectively. Floodplain soils and groundwater-affected soils are soil classes that are influenced by redoximorphic features and have a $4 \%$ share of total. This soil class is geographically widespread but often small-scaled distributed under forest due to their soil formation developing independently from bedrock. Terrestrial anthropogenic soils and cultivated peat soils 
have been altered strongly by human activity and accounted for $2 \%$ of the surveyed plots.

\subsection{Humus Forms}

Humus forms of German forest soils are distinguished according to the environmental conditions in terrestrial and hydromorphic humus forms. Terrestrial humus forms are formed under predominantly aerobic conditions and contain mull, moder and mor as well as their transitional forms. The hydromorphic humus forms hydromorphic mull, hydromorphic moder and hydromorphic mor as well as their transitional forms developed under intermittent anoxic conditions. The latter are hardly relevant in the NFSI collective covering $2 \%$ of the surveyed plots. Aerobic humus forms with a continuous fine humus horizon accounted for $52 \%$ of the plots, of which $16 \%$ is for mor-like moder and typical mor and $36 \%$ is for typical moder and rhizo moder. Terrestrial humus forms without a continuous fine humus horizon accounted for $46 \%$ of which $8 \%$ is for typical mull, $28 \%$ is for typical mull with Oe horizon and $10 \%$ is for moder-mull. The spatial distribution of humus forms showed a dominance of moder-like humus forms in the North German Lowland, while rhizo moder is less frequent in western parts of this landscape. Mor-like humus forms are present in the north-eastern parts of Germany, in East German mountain ranges and in the Bavarian Forest, while mull-like humus forms are dominating the middle and South of Germany (Fig. 2.4).

\subsection{Types of Depth Profiles of Base Saturation}

Soil acidification occurs under humid climate naturally very slowly as soil is weathered, but processes like tree uptake and acidic deposition can reduce the base saturation of the cation exchange capacity of the soil (Hartmann and von Wilpert 2016). Depending on soil properties and the supply of alkaline cations by mineral weathering, the soil profile is characterized by a depth-specific distribution of base saturation. The identified types of depth profiles of base saturation correspond with those described by von Wilpert (1996) and Kölling et al. (1996). Admittedly, an additional type which included sites that were limed was designated within the range of poor-base sites. A continuous high base saturation throughout the soil profile is represented by type 1 , while type 2 showed in the upper $30 \mathrm{~cm}$ of the soil a moderate but below $30 \mathrm{~cm}$ a high base saturation. Types 1 and 2 had a share of $14 \%$ and $4 \%$, respectively, of the surveyed plots. Moderate to low base saturation above $30 \mathrm{~cm}$ but moderate to high values in the soil below $30 \mathrm{~cm}$ provide a sufficient base supply of type 3 , who accounted for $8 \%$ of the surveyed plots. Type 4 is characterized by an increasing base depletion to a depth of $60 \mathrm{~cm}$ when the soil below is rich in base cations. In contrast, type 5 showed a base depletion throughout the whole soil profile. The proportions of the types amounted to $21 \%$ and $46 \%$, 


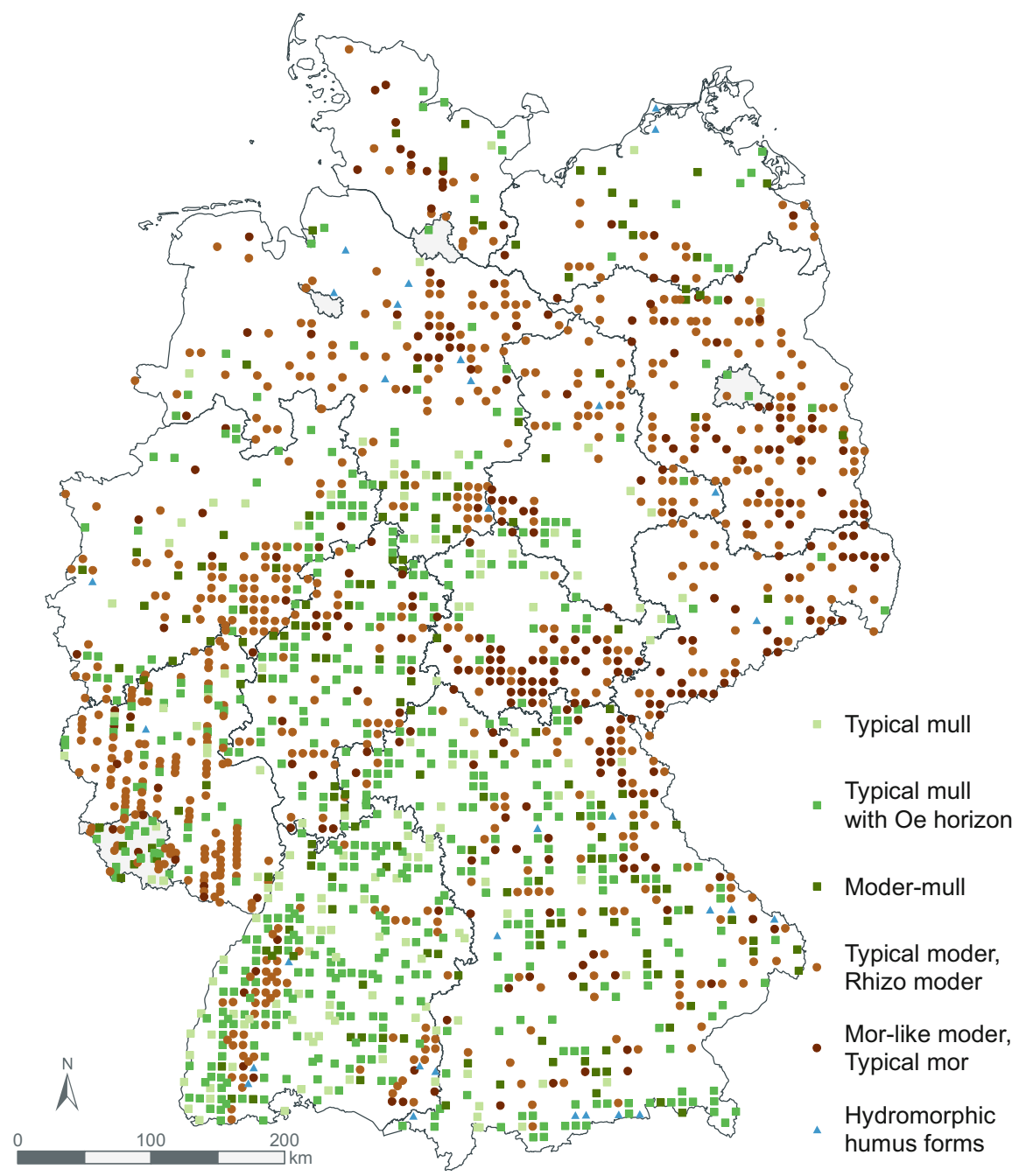

Fig. 2.4 Spatial distribution of humus forms on NFSI plots

respectively. Type 6 accounted for $7 \%$ of the surveyed plots. Since this type is very poor in base cations, liming of the forest brought base cations to organic layer and topsoil. Nevertheless, also other sites received lime; the effects, however, showed no clear effects in the mineral soil (Fig. 2.5). 

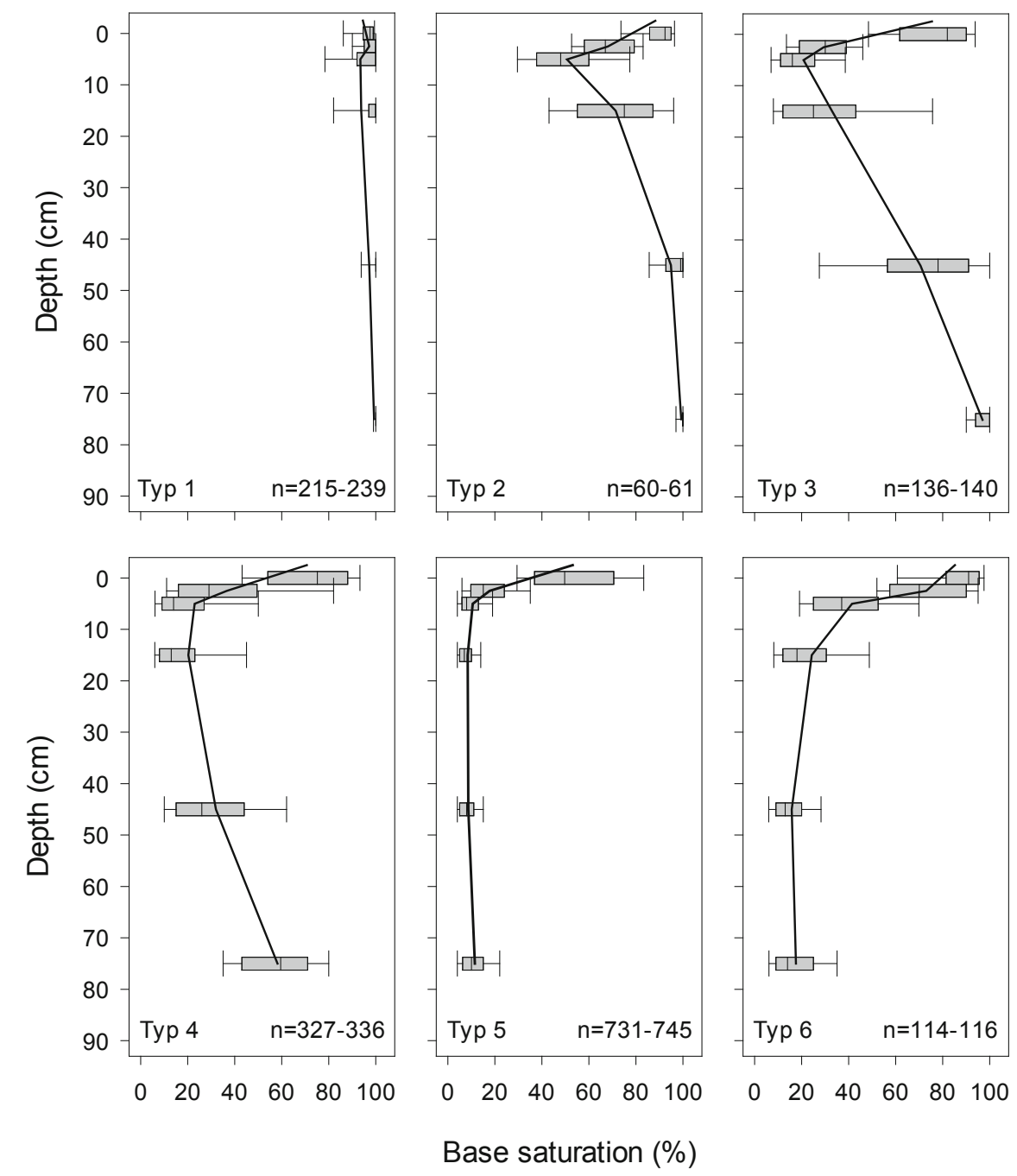

Fig. 2.5 Types of depth profiles of base saturation

\subsection{Acid-Sensitive Sites}

The purpose of liming forest soils in Germany was primarily the mobilization of $\mathrm{N}$ from a biological inactive organic layer to compensate effects of soil acidification. From the mid-1980s, most of the federal states started to lime to (1) compensate soil acid loads and current acid inputs, (2) improve growth conditions for microorganisms and root systems, (3) offset acidification-related loss of nutrient cation and imbalances in forest nutrition due to high $\mathrm{N}$ depositions, (4) improve vitality of forest stands and (5) protect spring and groundwater from inputs of heavy metals, 
toxic aluminium and/or acids. Federal state-specific liming with respect to liming concepts is suitable to lime. We defined all plots which reach the criteria for liming as sensitive to acidification (Höhle et al. 2018, pp. 11-42). Exclusively on such sites, effects of liming can be analysed by comparing limed and non-limed sites of the first and second NFSI. Of the total of 1859 surveyed plots of the NFSI II, 749 sites were acid sensitive. Of those 385 sites were limed at least once since the first inventory. Concepts adapted to site-specific requirements were developed for an efficient and long-lasting regeneration of essential soil functions. The identified acid-sensitive sites comprise soils that in respect to liming concepts are suitable to lime. Exclusively on such sites, effects of liming can be analysed by comparing limed and non-limed sites of the first and second NFSI. Of the total of 1859 surveyed plots of the NFSI II, 749 sites were acid sensitive. Of those 385 sites were limed at least once since the first inventory (Fig. 2.6).

\subsection{Forest Stands}

Forest stands play an important role in characterizing ecological conditions of a forest site. The forest stand type was designated for each of the NFSI plots according to the dominant principle species and mixing of various tree species, respectively. Specific forest stand information was obtained in more detail on NFSI plots with the harmonized stand inventory (HIS; Hilbrig et al. 2014). Data from the National Forest Inventory was used for surveyed plots of Bavaria (BMEL 2014). The NFSI distinguished pure stands with a share of $70 \%$ of principle tree species, while the HSI accounted for $90 \%$ of principle tree species to characterize pure stands. Dominant forest stands of the NFSI II were pure spruce "Spruce, pure" and pine "Pine, pure" stands accounting for $25 \%$ and $22 \%$ of the surveyed plots. The most frequent broadleaf tree species was beech "Beech, pure" with a share of $16 \%$. The stands with other broadleaf species "Broadleaf, others" and mixed coniferous-broadleaf stands "Broadleaf, rich in coniferous" accounted for $10 \%$, with a share of $6 \%$ followed oak stands "Oak, pure" and other coniferous stands "Coniferous, others". The smallest proportion with 5\% was found for mixed broadleaf-coniferous stands "Coniferous, rich in broadleaf". The HSI revealed a proportion of $46 \%$ of coniferous stands "Coniferous, pure". Adding the class "Coniferous, dominated" (13\%) to coniferous pure stands, this is demonstrating the dominance of coniferous trees on surveyed plots. The class "Broadleaf, pure" and "Broadleaf, dominated" accounted for $29 \%$ and $8 \%$ of the surveyed plots. Even more rarely are mixed broadleaf and coniferous stands "Mixed" with a share of $4 \%$. The spatial distribution of forest stands showed that broad areas of Northern German Lowlands are stocked with pine stands. By transgressing the mountain range, the spatial distribution of forest stands is changing towards spruce and beech as well as mixed stands, the former dominates the mountain range and the latter, however, is characterizing the undulating lowlands and hilly areas. Most oak stands are scattered distributed in western parts of Germany (Fig. 2.7). 


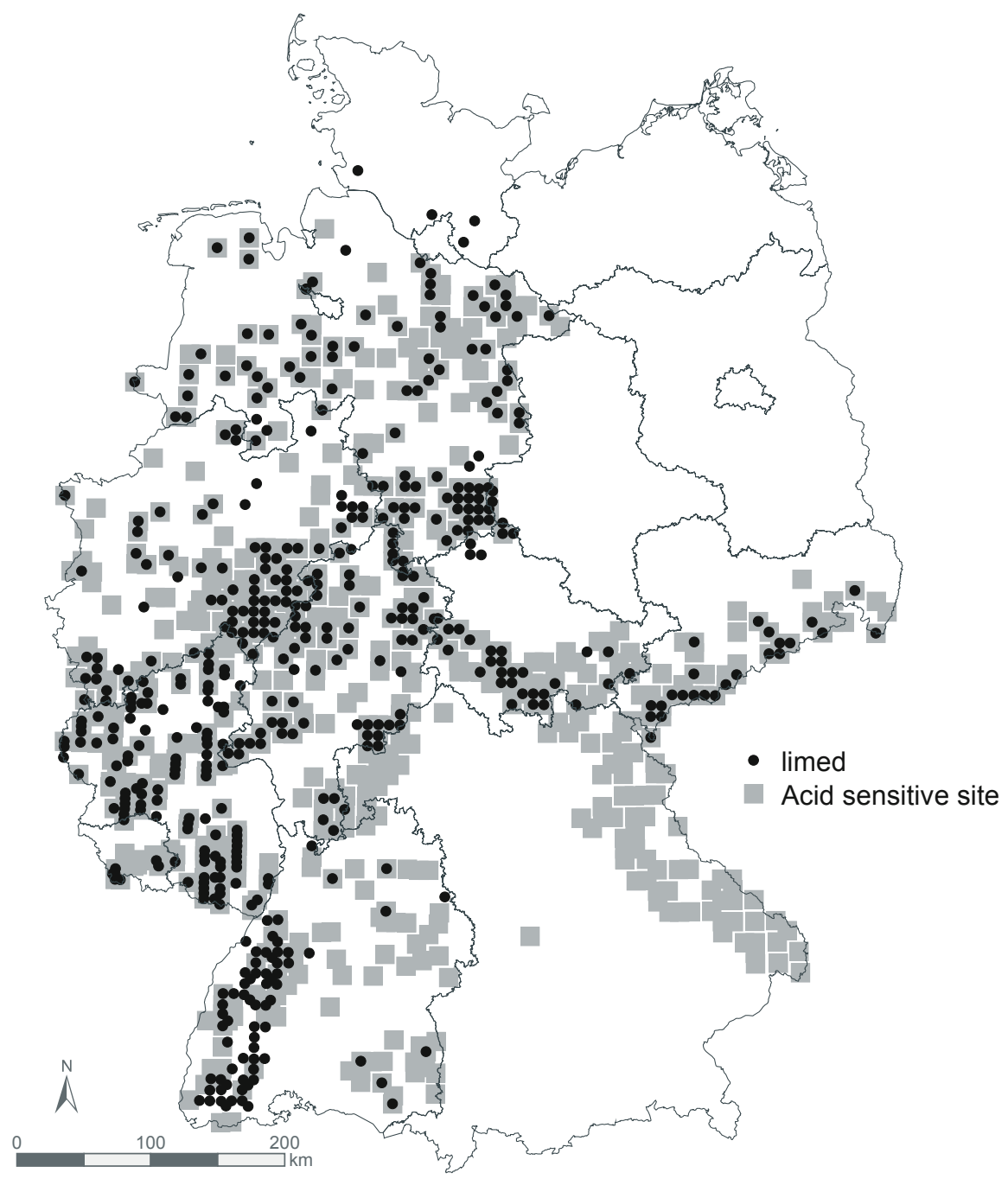

Fig. 2.6 Spatial distribution of acid-sensitive sites and limed NFSI plots

\subsection{Classification of Forests Based on the Atmospheric Deposition}

In order to determine the characteristic deposition patterns of forests in Germany during NFSI I and NFSI II, a factor analysis linked to a cluster analysis was performed using the modelled deposition data (Fig. 2.1). The mean of the deposition data from 1990 to 1993 were used for the period of NFSI I and the mean of 2004 to 2007 was used for the period of NFSI II. Evaluations were done using the statistic software R 3.4.1 (R Core Team 2017). Explorative maximum-likelihood factor 

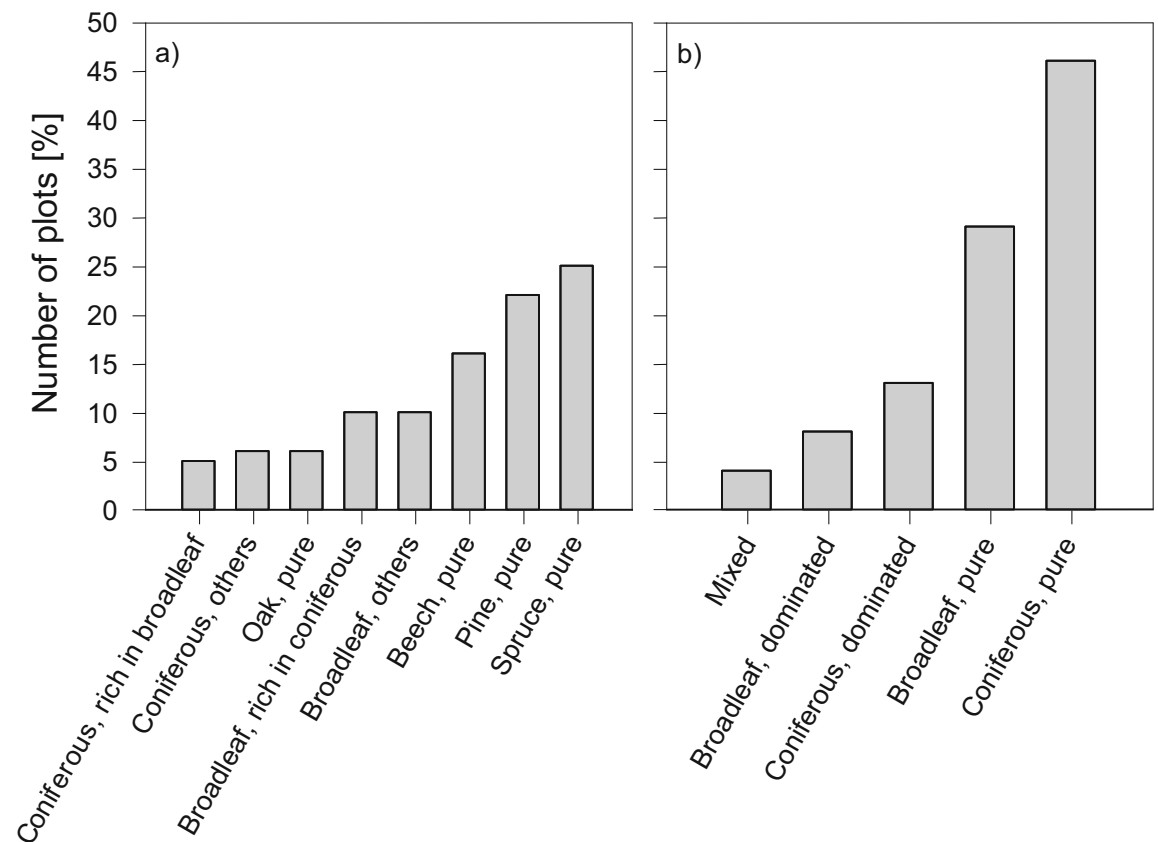

Fig. 2.7 Distribution of forest stand types at NFSI II differentiated according to (a) main tree species and (b) broadleaves and coniferous stands

Table 2.1 Loading values of the deposition factors obtained from the deposition components by factor analysis with varimax rotation

\begin{tabular}{l|l|l|l|l|l|l}
\hline & \multicolumn{4}{|l|}{ Deposition factor 1990-1993 } & \multicolumn{3}{l}{ Deposition factor 2004-2007 } \\
\cline { 2 - 8 } Deposition component & 1 & 2 & 3 & 1 & 2 & 3 \\
\hline $\mathrm{N}_{\text {tot }}$ & 0.63 & 0.77 & & 0.89 & 0.43 & \\
\hline $\mathrm{NH}_{x}-\mathrm{N}$ & 0.21 & 0.96 & & 0.98 & & \\
\hline $\mathrm{NO}_{y}-\mathrm{N}$ & 0.99 & & & & 0.98 & \\
\hline $\mathrm{SO}_{x}-\mathrm{S}$ & 0.61 & & -0.22 & & 0.64 & -0.31 \\
\hline $\mathrm{Ca}$ & 0.21 & & 0.98 & & 0.22 & 0.97 \\
\hline $\mathrm{Mg}$ & & & 0.72 & & & 0.70 \\
\hline $\mathrm{K}$ & 0.42 & & 0.31 & 0.32 & 0.49 & 0.32 \\
\hline $\mathrm{Cl}$ & & 0.46 & & 0.48 & & \\
\hline Explained variance (\%) & 26 & 22 & 21 & 26 & 23 & 22 \\
\hline$\Sigma$ explained variance (\%) & 69 & & & 71 & & \\
\hline
\end{tabular}

analysis with varimax rotation was applied on log-transformed deposition data. The factor analysis identified three independent deposition factors for each inventory which explained 69\% (NFSI I) and 71\% (NFSI II), respectively, of the total variability within the deposition data (Table 2.1).

During NFSI I the factor which explained most variability was mainly loaded by oxidized $\mathrm{N}$ compounds $\left(\mathrm{NO}_{y}-\mathrm{N}\right)$ but also by $\mathrm{S}$ compounds $\left(\mathrm{SO}_{x}-\mathrm{S}\right)$, followed by a factor which was mainly loaded by reduced $\mathrm{N}$ compounds $\left(\mathrm{NH}_{x}-\mathrm{N}\right)$ and total $\mathrm{N}$ 


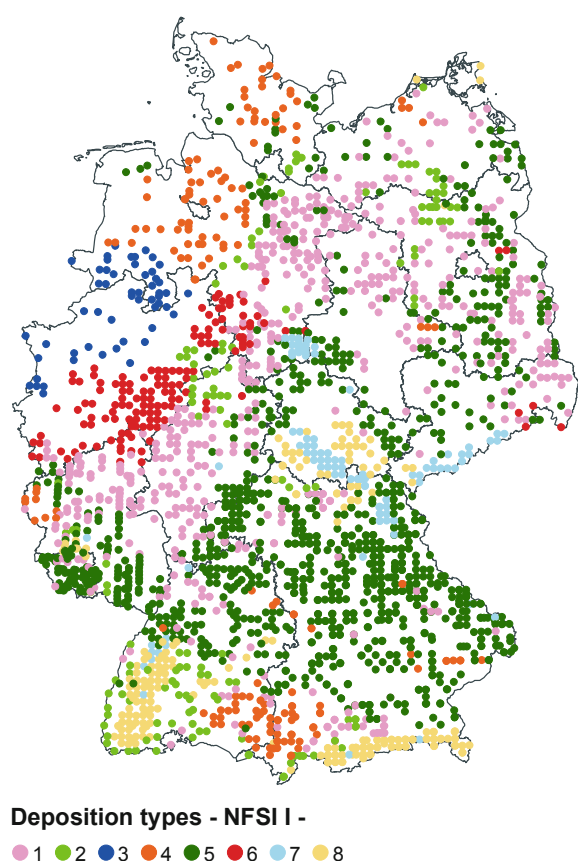

○ $2 \bigcirc 3 \bigcirc 4 \bigcirc 5 \bullet 6 \bigcirc 7 \bigcirc 8$

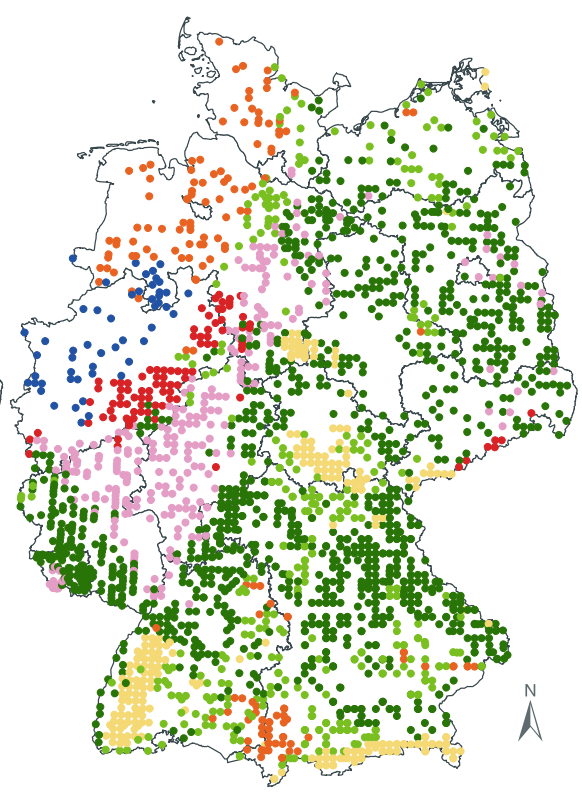

Deposition types - NFSI II -

$\bullet 1 \bullet 2 \bullet 3 \bullet 4 \quad 5 \bullet 6 \bullet$

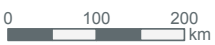

Fig. 2.8 Spatial distribution of atmospheric deposition types obtained by a model-based cluster analysis on basis of the deposition factors for the time period 1990-1993 (NFSI I, left side) and 2004-2007 (NFSI II, right side)

deposition. During NFSI II, the factor which was mainly loaded by reduced $\mathrm{N}$ compounds and total $\mathrm{N}$ deposition gained importance compared to NFSI I, whereas the factor which was mainly loaded by oxidized $\mathrm{N}$ compounds and $\mathrm{S}$ compounds was only at second place. A third deposition factor which showed similar importance during both time periods was loaded by base cations particularly by calcium and magnesium.

A model-based cluster analysis (R package mclust, version 5.3; Fraley et al. 2017) was conducted on basis of the three deposition factors for each time period. Eight clusters (atmospheric deposition types) were obtained for the first period (NFSI I) and seven clusters for the second period (NFSI II) (Fig. 2.8).

Cluster 1 (NFSI I) could be found in large areas of former eastern Germany and the adjacent eastern part of Lower Saxony as well as in the majority of Hesse and in north-eastern Rhineland-Palatinate. The cluster was characterized by average depositions from industry and traffic and low depositions from agriculture and base cations. During NFSI II the mentioned part of eastern Germany and north-eastern Lower Saxony fell into Cluster 4. The mentioned parts of south-eastern Lower Saxony, Hesse and north-eastern Rhineland-Palatinate fell into Cluster 6 (still low 
depositions from agriculture and base cation but higher inputs from industry and traffic compared to Cluster 4 and eastern Germany) during NFSI II.

Cluster 2 (NFSI I) comprised comparably few plots which were spread, e.g. around the Black Forest. The cluster was characterized by average depositions from agriculture and base cation and low inputs from industry and traffic. These plots mainly also fell in Cluster 2 of NFSI II. However, Cluster 2 of NFSI II could be found more widespread than Cluster 2 of NFSI I.

Cluster 3 (NFS II) could be found relative locally in the lowland of North RhineWestphalia and the adjacent south-western lowland of Lower Saxony. The cluster showed very high inputs from industry and traffic as well as from agriculture but very low base cation inputs. The cluster still existed during NFSI II where it was Cluster 7.

Cluster 4 (NFSI I) was located in the western part of Lower Saxony, in Schleswig-Holstein and in the border area between Baden-Wuerttemberg and Bavaria. The cluster also existed during NFSI II (Cluster 3) and was characterized by very high depositions from agriculture, average inputs of base cations and low to average inputs from industry and traffic.

Cluster 5 (NFSI I) comprised large areas especially in the southern part of Germany ranging from Bavaria to Saarland and was characterized by average inputs regarding all three input sources. The cluster was the dominating cluster during NFSI II (Cluster 4). Besides the mentioned areas, also large areas of former eastern Germany fell into this cluster during NFSI II.

Cluster 6 (NFSI I) could primarily be found in the mountainous regions of North Rhine-Westphalia but also in the adjacent mountainous regions of Lower Saxony. The cluster was present during NFSI II (Cluster 1), as well. Inputs from industry and traffic were very high, inputs from agriculture were average to high and base cation depositions were low.

Cluster 7 (NFSI I) could be found in the western part of the Harz, in the Thuringian Forest, in the Ore Mountains and in the Fichtel Mountains, which were all characterized by former intensive mining activities and very high inputs from industry and base cations. This cluster did no longer exist during NFSI II. The plots mainly fell into Cluster 5 (NFSI II), which also showed very high base cation inputs but high inputs from industry and traffic and average input from agriculture.

Cluster 8 (NFSI I) comprised the Black Forest, the Alps, parts of the Alpine Uplands and the Thuringian Basin. Base cation inputs were very high due to the calcareous parent material of the mountainous regions themselves or the adjacent areas. This cluster to a great extent still existed during NFSI II (Cluster 5) but was enlarged by the former Cluster 7 (NFSI I). Depositions from agriculture were low, and depositions from industry and traffic were average.

In conclusion, though atmospheric inputs especially from industry and traffic declined in most regions, regional patterns of deposition exhibited little changes between NFSI I and NFSI II in particular regarding former Western Germany. However in Bavaria some plots changed the deposition type (Cluster 5 of NFSI I to Cluster 2 of NFSI II) due to a decrease of depositions from industry and traffic accompanied by an increase of depositions from agriculture. Reductions in inputs 
from industry and traffic further resulted in a change of deposition type of several plots in the north-eastern lowlands. Stronger alteration in the deposition types however could be observed in the mountainous areas characterized by intensive mining activities and industry in the past (Harz, Thuringian Forest, Ore Mountains, Fichtel Mountains). The western part of the Harz was additionally affected by pollution derived from the Ruhr Area. Cluster 7 became no longer necessary during NFSI II due to a significant decrease in $\mathrm{SO}_{x}, \mathrm{NO}_{y}$ and base cation depositions. A factor which was mainly loaded by reduced $\mathrm{N}$ compounds $\left(\mathrm{NH}_{x}-\mathrm{N}\right)$ and total $\mathrm{N}$ deposition became more important. Thus, the importance of emissions from industry and traffic slightly decreased, while the importance of emissions from agriculture increased.

\subsection{Critical Loads for Eutrophication and Acidification and Their Exceedance}

Continuous immissions of the airborne pollutants sulphate, nitrate and ammonia can cause indirect (soil-mediated) damage to forest ecosystems by acidification, eutrophication and nutrient imbalances. Critical loads of $\mathrm{S}$ and $\mathrm{N}$ are defined as the annual deposition rate below which no long-term harmful effects on ecosystem structure and function are expected according to present knowledge (Nilsson and Grennfelt 1988). The starting points for critical loads calculations are the receptor systems in need for protection. In forest ecosystems, the considered receptors are trees, ground vegetation and soil. Critical limits are no-effect concentration thresholds in the soil solution used to calculate critical loads with a simple mass balance approach (see Chap. 1). Regarding acidification, critical limits are set to prevent toxic reactions of solved acidogenic cations $\left(\mathrm{Al}^{3+}, \mathrm{H}^{+}\right)$on tree roots, the shift to a site-specific atypical buffer range, irreversible damage of soil structure and decline of base saturation under a tolerable threshold for the plant community. Critical limits for nutrient $\mathrm{N}$ are set to prevent changes in the plant community and nutrient imbalances in trees. Waldner et al. (2015) showed that exceedance of critical loads for nutrient nitrogen $\left(\mathrm{CL}_{\text {nut }}(\mathrm{N})\right)$ leads to nutrient imbalances in the foliage.

\subsubsection{Parameters for Critical Loads Calculation Derived from NFSI II Data}

Estimated and measured parameters used for critical loads calculation are based on NFSI data (Höhle et al. 2018). Estimated base cation (Ca, Mg, K) weathering rate $\left(\mathrm{Bc}_{\mathrm{w}}\right)$ varied substantially with soil parent material and rooting depth with a median of $0.8 \mathrm{keq} \mathrm{ha}^{-1}$ year $^{-1}$ (Table 2.2). Base cation and $\mathrm{N}$ uptake $\left(\mathrm{Bc}_{\mathrm{u}}, \mathrm{N}_{\mathrm{u}}\right)$ amounted to $0.5 \pm 0.00 \mathrm{keq} \mathrm{ha}^{-1}$ year $^{-1}$ and $5.9 \pm 0.04 \mathrm{~kg} \mathrm{ha}^{-1}$ year $^{-1}$, respectively. 
Table 2.2 Parameters for critical loads calculation and critical limits

\begin{tabular}{|c|c|c|c|c|c|c|}
\hline Parameter & & Min & $\mathrm{P}_{25}$ & $\mathrm{P}_{50}$ & $\mathrm{P}_{75}$ & Max \\
\hline $\mathrm{Bc}_{\mathrm{w}}$ & keq ha ${ }^{-1}$ year $^{-1}$ & 0.03 & 0.44 & 0.80 & 1.50 & 13.44 \\
\hline $\mathrm{Bc}_{\mathrm{u}}$ & keq ha ${ }^{-1}$ year $^{-1}$ & 0.12 & 0.37 & 0.46 & 0.58 & 0.85 \\
\hline $\mathrm{N}_{\mathrm{u}}$ & $\mathrm{kg} \mathrm{ha}^{-1}$ year $^{-1}$ & 1.54 & 4.60 & 5.79 & 7.05 & 13.27 \\
\hline $\mathrm{N}_{\mathrm{de}} \bmod$ & $\mathrm{kg} \mathrm{ha}^{-1}$ year $^{-1}$ & 0.00 & 0.11 & 0.40 & 1.17 & 61.70 \\
\hline $\mathrm{N}_{\mathrm{de}}$ cons & $\mathrm{kg} \mathrm{ha}^{-1}$ year $^{-1}$ & 0.00 & 0.04 & 0.11 & 0.25 & 17.78 \\
\hline $\mathrm{N}_{\mathrm{i}}$ glacial & $\mathrm{kg} \mathrm{ha}^{-1}$ year $^{-1}$ & 0.18 & 0.32 & 0.47 & 0.84 & 5.41 \\
\hline $\mathrm{N}_{\mathrm{i}}$ periglacial & $\mathrm{kg} \mathrm{ha}^{-1}$ year $^{-1}$ & 0.04 & 0.20 & 0.27 & 0.37 & 1.78 \\
\hline $\mathrm{ANC}_{\mathrm{le}, \mathrm{crit}}$ & keq ha ${ }^{-1}$ year $^{-1}$ & -7.77 & -1.02 & -0.40 & -0.03 & 3.11 \\
\hline $\mathrm{N}_{\mathrm{le}, \mathrm{acc}} \bmod$ & $\mathrm{kg} \mathrm{ha}^{-1}$ year $^{-1}$ & 0.00 & 0.81 & 2.22 & 5.24 & 59.99 \\
\hline $\mathrm{N}_{\mathrm{le}, \mathrm{acc}}$ cons & $\mathrm{kg} \mathrm{ha}^{-1}$ year $^{-1}$ & 0.00 & 0.25 & 0.62 & 1.21 & 7.10 \\
\hline
\end{tabular}

$B c_{w}$ base cation weathering rate, $B c_{u}$ base cation uptake, $N_{u}$ nitrogen uptake, $N_{d e} \bmod$ denitrification rate in the modified approach, $N_{d e}$ cons denitrification rate in the conservative approach, $N_{i}$ glacial nitrogen immobilization rate on glacial sites, $N_{i}$ periglacial nitrogen immobilization rate on periglacial sites, $A N C_{l e, c r i t}$ critical leaching of acid-neutralizing capacity, $N_{l e, a c c} \bmod$ acceptable $\mathrm{N}$ leaching in the modified approach, $N_{l e, a c c}$ cons acceptable $\mathrm{N}$ leaching in conservative approach

Denitrification rate $\left(\mathrm{N}_{\mathrm{de}}\right)$ was higher in the modified approach according to Balla et al. (2013) and ARGE_StickstoffBW (2014) than with conservative critical limits assumptions (Table 2.2, see Chap. 1). Nitrogen immobilization rate $\left(\mathrm{N}_{\mathrm{i}}\right)$ was estimated as 0.5 and $0.3 \mathrm{~kg} \mathrm{ha}^{-1}$ year $^{-1}$ on glacial and periglacial sites referring to the last glacial maximum, respectively.

\subsubsection{Critical Limits and Critical Loads}

The critical leaching of acid-neutralizing capacity $\left(\mathrm{ANC}_{\mathrm{le}, \mathrm{crit}}\right.$; see Chap. 1) was calculated from the most stringent of five chemical soil criteria. The criterion to prevent aluminium toxicity on tree roots allowed the least leaching rates on most plots in siliceous low mountain ranges and the Northern German Plain. The critical base cation to aluminium ratio ( $\mathrm{Bc} / \mathrm{Al})_{\text {crit }}$ (see Chap. 1) was effective on $62 \%$ of the plots. It was most important for pine stands $(83 \%)$, which are more vulnerable to aluminium toxicity, but only relevant for $23 \%$ of other broadleaf stands. The critical base cation to proton ratio $(\mathrm{Bc} / \mathrm{H})_{\text {crit }}$ (see Chap. 1) was relevant for $71 \%$ of the peat and peaty mineral soils ( $2 \%$ of the NFSI plots, mostly covered by other broadleaf stands). A critical $\mathrm{pH}$ to preserve the soil typical buffer range was only considered for soils with base saturation $>30 \%$ and was relevant for $84 \%$ of those $(33 \%$ of the NFSI plots). Accordingly, it was underrepresented on all coniferous and overrepresented on all broadleaf stands. The critical aluminium mobilization rate $\left(\mathrm{Al}_{\mathrm{w}}\right)$ to maintain soil structure determined $\mathrm{ANC}_{\mathrm{le} \text {,crit }}$ on only $1 \%$ of all NFSI plots, mostly other coniferous forests ( $13 \%$ of those). Critical base saturation was also relevant for only $1 \%$ of the plots. Median $\mathrm{ANC}_{\mathrm{le}, \text { crit }}$ was at $-0.4 \mathrm{keq} \mathrm{ha}^{-1} \mathrm{year}^{-1}$ (Table 2.2). 

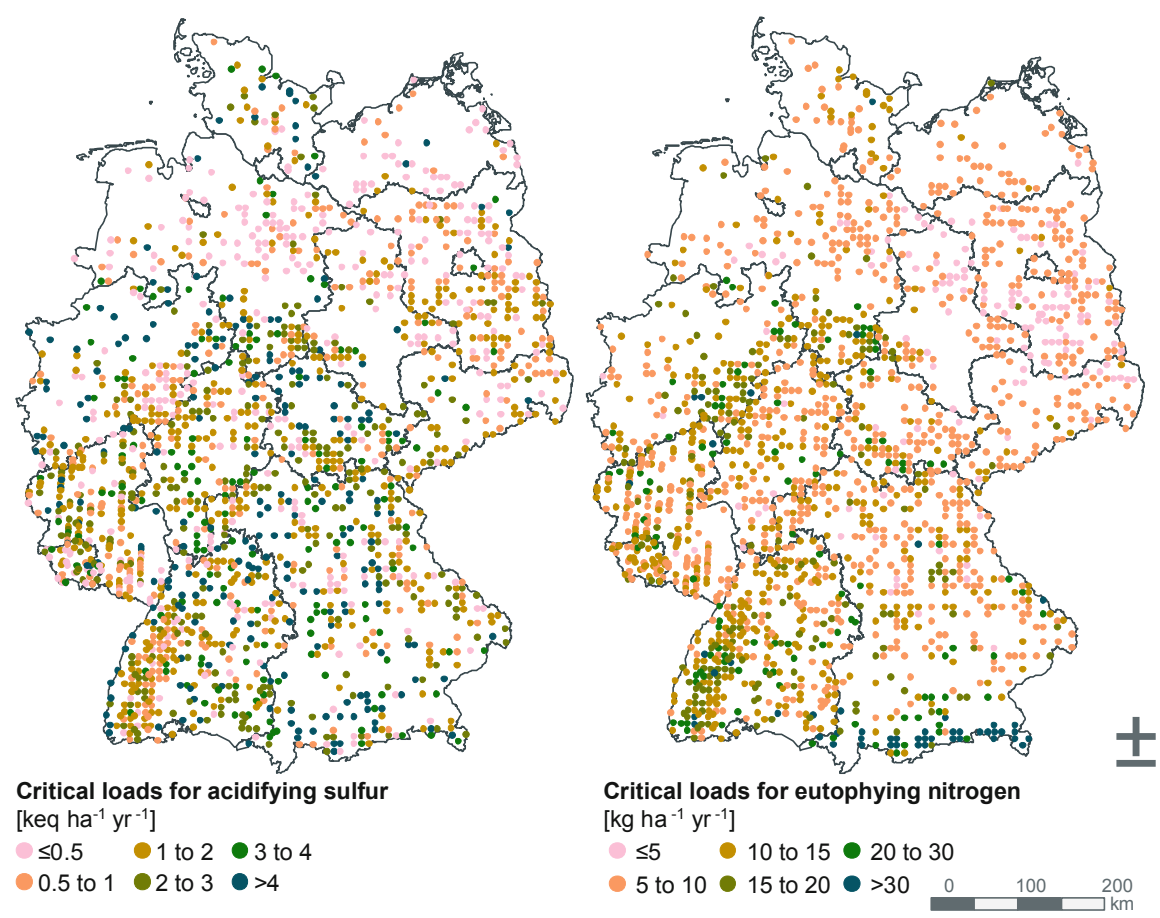

Fig. 2.9 Geographical distribution of critical loads for acidifying sulphur $\left(\mathrm{CL}_{\max }(\mathrm{S})\right)$ and eutrophying nitrogen $\left(\mathrm{CL}_{\text {nut }}(\mathrm{N})\right)$ on NFSI plots

The magnitude and geographical distribution of critical loads for acidifying sulphur $\mathrm{CL}_{\max }(\mathrm{S})$ (see Chap. 1, Fig. 2.9) were strongly determined by the weathering rate of base cations $(r=0.91)$. Consequently, $\mathrm{CL}_{\max }(\mathrm{S})$ was lowest on soils from base-poor unconsolidated sediment and organic soils and peaty mineral soils $\left(1.2 \pm 0.1 \mathrm{keq} \mathrm{ha}^{-1}\right.$ year $^{-1}$ and $1.1 \pm 0.5 \mathrm{keq} \mathrm{ha}^{-1}$ year $^{-1}$, respectively $)$ and highest on loessic loam in the lowlands and calcareous soils $\left(3.3 \pm 0.2 \mathrm{keq} \mathrm{ha}^{-1}\right.$ year $^{-1}$ and $3.9 \pm 0.2 \mathrm{keq} \mathrm{ha}^{-1}$ year $^{-1}$, respectively). Mean $\mathrm{CL}_{\max }(\mathrm{S})$ ranged from $1.3 \pm 0.1 \mathrm{keq} \mathrm{ha}^{-1}$ year $^{-1}$ on pine stands up to $3.3 \pm 0.4 \mathrm{keq} \mathrm{ha}^{-1} \mathrm{year}^{-1}$ on other broadleaf forest stands (Fig. 2.10).

Critical limits of the $\mathrm{N}$ concentration in the soil solution for eutrophying nitrogen $\left(\mathrm{N}_{\text {crit }}\right)$ were calculated according to the modified approach (see Chap. 1) as $1.3 \pm 0.03 \mathrm{mg} \mathrm{l}^{-1}$ for near-natural forest ecosystems and $1.5 \pm 0.04 \mathrm{mg} \mathrm{l}^{-1}$ for planted forests. The resulting acceptable $\mathrm{N}$ leaching $\left(\mathrm{N}_{\mathrm{le}, \text { acc }}\right)$ amounted to $4.0 \pm 0.12 \mathrm{~kg} \mathrm{ha}^{-1}$ year $^{-1}$ as compared to $0.9 \pm 0.02 \mathrm{~kg} \mathrm{ha}^{-1}$ year $^{-1}$ when computed from the conservative approach with $\mathrm{N}_{\text {crit }}=0.2-0.4 \mathrm{mg}^{-1} \mathrm{~N}$ (Table 2.2). The high limits of leaching rates in the modified approach may not protect the ecosystems from nutrient imbalances in all cases. We therefore consider non-exceedance of $\mathrm{CL}_{\text {nut }}(\mathrm{N})$ but exceedance of $\mathrm{CL}_{\text {nut }}(\mathrm{N})_{\text {cons }}$ from the conservative approach (see Chap. 1) as risk of potential exceedance. 
Fig. 2.10 Relative frequency of critical loads for acidifying sulphur $\left(\mathrm{CL}_{\max }(\mathrm{S})\right)$ on NFSI plots on different forest stand types. $B e$ beech $n=226, O a$ oak $n=97, S p$ spruce $n=424$, $P i$ pine $n=353, B L$ other broadleaf stand $n=101, M i$ mixed stand $n=503, C o$ other coniferous stand $n=60$
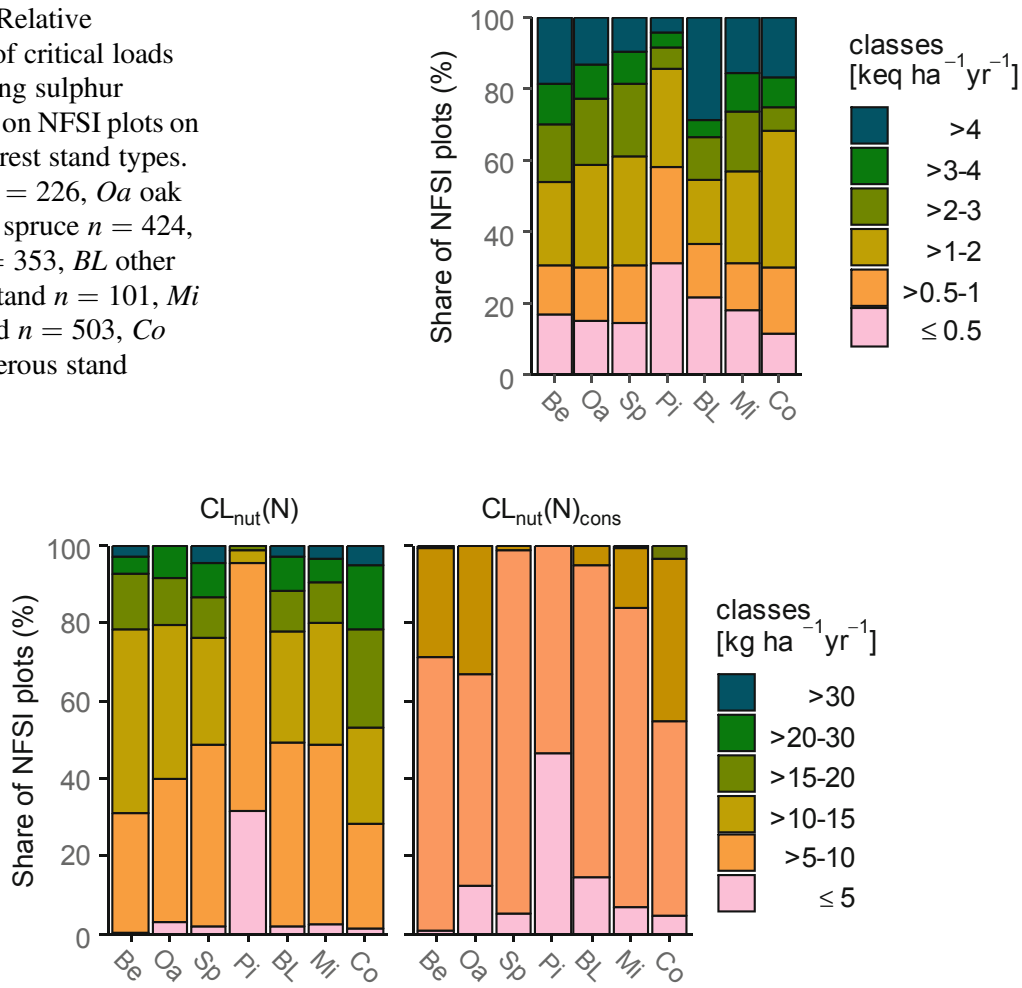

Fig. 2.11 Relative frequency of critical loads for eutrophying nitrogen $\left(\mathrm{CL}_{\mathrm{nut}}(\mathrm{N})\right)$ calculated after the modified $\left(\mathrm{CL}_{\text {nut }}(\mathrm{N})\right)$ and the conservative approach $\left(\mathrm{CL}_{\text {nut }}(\mathrm{N})_{\text {cons }}\right)$ on NFSI plots on different forest stand types (Fig. 2.10)

The mean $\mathrm{CL}_{\mathrm{nut}}(\mathrm{N})$ was determined at $11.3 \pm 0.17 \mathrm{~kg} \mathrm{ha}^{-1}$ year $^{-1}$, with considerable variation among forest stand types. It ranged from $6.0 \pm 0.12 \mathrm{~kg} \mathrm{ha}^{-1}$ year $^{-1}$ for pine stands, followed by oak, other broadleaf and mixed stands $\left(11.9 \pm 0.48,12.0 \pm 0.63\right.$ and $12.0 \pm 0.34 \mathrm{~kg} \mathrm{ha}^{-1}$ year $^{-1}$, respectively), over $13.0 \pm 0.40 \mathrm{~kg} \mathrm{ha}^{-1}$ year $^{-1}$ for beech and spruce stands, up to $15.7 \pm 1.19 \mathrm{~kg} \mathrm{ha}^{-1}$ year $^{-1}$ for other coniferous stands (Fig. 2.11). These modelled values are in good agreement with empirical critical loads (Bobbink and Hettelingh 2011). Values for $\mathrm{CL}_{\text {nut }}(\mathrm{N})$ cons were generally lower $\left(7.3 \pm 0.05 \mathrm{~kg} \mathrm{ha}^{-1} \mathrm{year}^{-1}\right)$, with similar distribution among the stand types (Fig. 2.11). For the geographical distribution of $\mathrm{CL}_{\text {nut }}(\mathrm{N})$ (Fig. 2.11), seepage water is the most important influential factor $(r=0.66)$.

Almost all NFSI plots (91\%) are more vulnerable to the eutrophying effect of $\mathrm{N}$ than to its acidifying effect $\left(\mathrm{CL}_{\text {nut }}(\mathrm{N})<\mathrm{CL}_{\max }(\mathrm{N})\right)$. 


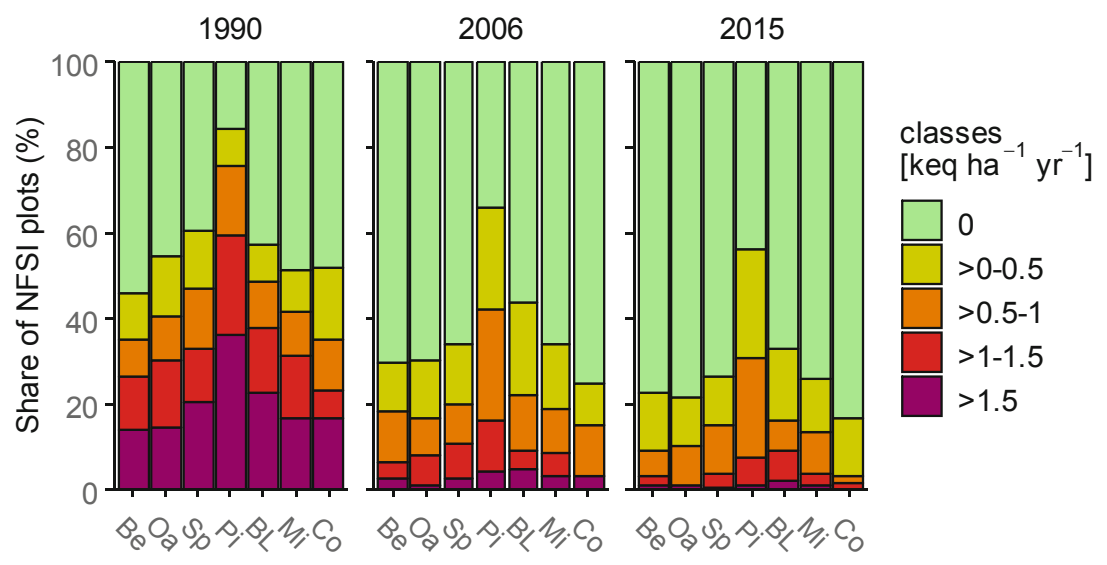

Fig. 2.12 Relative frequency of exceedance of the CL function for acidity $\left(C_{2} F_{\text {aci }}\right)$ on NFSI plots in 1990, 2006 and 2015 on different forest stand types (Fig. 2.10)

\subsubsection{Exceedance of Critical Loads}

Since 1990, the measures of air pollution control succeeded in reducing extreme

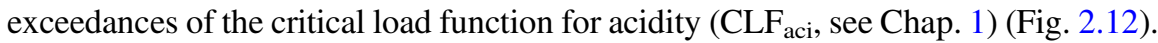
Nevertheless, $40 \%$ of the NFSI plots were still exposed to loads of acidifying S and $\mathrm{N}$ beyond the long-term buffering capacity in 2006. Most threatened were pine stands with exceedance on $66 \%$ of the plots in 2006. Most compromised were the forests in north-western and eastern Germany (Fig. 2.13).

The exceedance of $\mathrm{CLF}_{\mathrm{aci}}$ was higher for $\mathrm{S}$ than for $\mathrm{N}$ on $84 \%$ of the compromised plots in 1990 and still on $68 \%$ in 2006. In the meantime, the share of compromised plots where the exceedance of acidifying $\mathrm{N}$ went far beyond $\mathrm{S}$ exceedance (ExN-ExS $>0.1 \mathrm{keq} \mathrm{ha}^{-1}$ year $^{-1}$ ) increased from 12 to $25 \%$, while the share of surpassing $\mathrm{S}$ exceedance decreased from 21 to $4 \%$. This development reflects the increasing role of $\mathrm{N}$ as acidifying pollutant, which is most substantial in the regions of high agricultural $\mathrm{N}$ emissions. The further development from 2006 to 2015 is characterized by reduction of extreme exceedances, while a substantial share of plots with moderate exceedance remained (Fig. 2.12).

Since 1990, the extreme exceedances $\left(>10 \mathrm{~kg} \mathrm{ha}^{-1}\right.$ year $\left.^{-1}\right)$ of $\mathrm{CL}_{\mathrm{nut}}(\mathrm{N})$ declined due to the reduction of $\mathrm{N}$ emissions (Fig. 2.14). However, in 2006, 85\% of the NFSI plots were still exposed to critical $\mathrm{N}$ deposition, causing prospective vegetation changes and/or nutrient imbalances, and only $4 \%$ were beyond the risk of potential $\mathrm{N}$ exceedance. The highest exceedances occurred in the north-western lowlands and in central/eastern Germany on sandy soils and acid bedrocks (Fig. 2.13). The threat was most pronounced for pine stands with $\mathrm{N}$ exceedance on $99 \%$ of the plots and exceedance $>10 \mathrm{~kg} \mathrm{ha}^{-1}$ year $^{-1}$ on $81 \%$ (Fig. 2.13). The share of plots with definite $\mathrm{N}$ exceedance of the other forest stand types ranged from $56 \%$ for other coniferous stands ( $2 \%$ without risk of exceedance) up to $80 \%$ for other broadleaf forests $(0 \%$ 


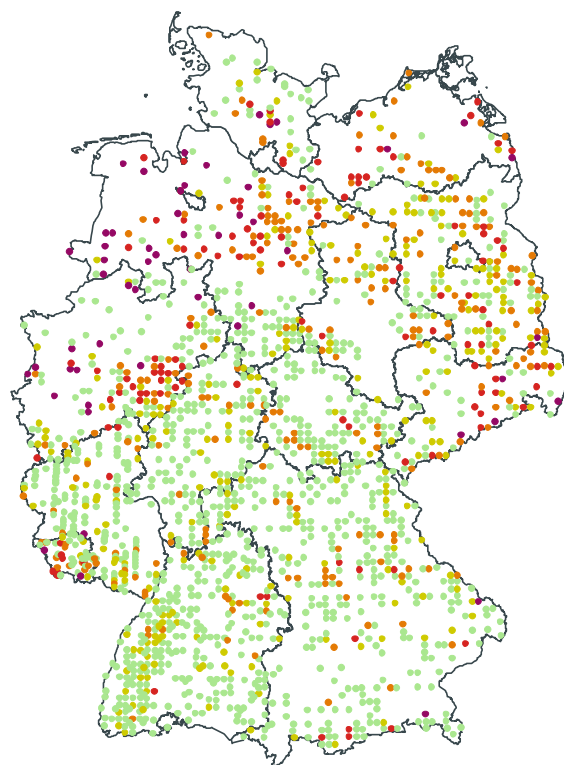

Exceedance of the critical loads function for acidity [keq ha ${ }^{-1} \mathrm{yr}^{-1}$ ]

$\begin{aligned} 0 & >0.5 \text { to } 1 \\ >0 & \text { to } 0.5>1.5\end{aligned}$

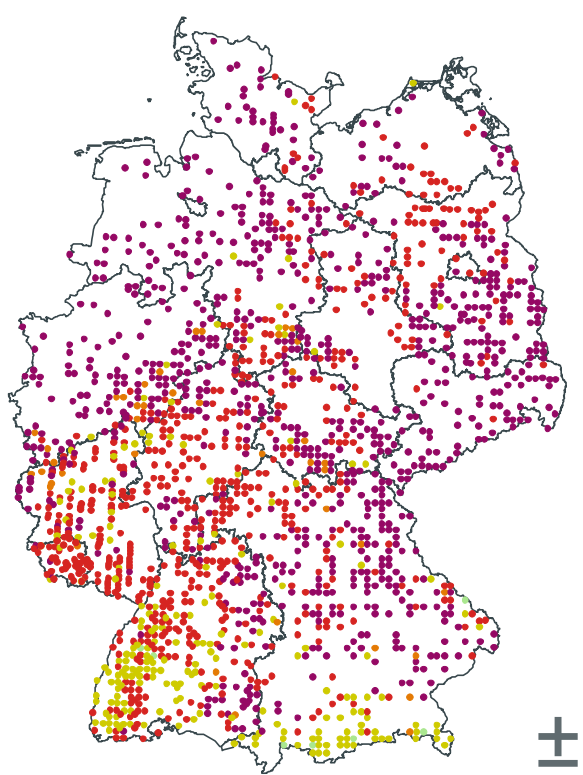

Exceedance risk of eutrophying nitrogen [kg ha $\left.{ }^{-1} \mathrm{yr}^{-1}\right]$
0
pot. Ex $>10$ Ex $>10$
pot. Ex $<10$ Ex $<10$
\begin{tabular}{llr}
0 & $100 \quad 200$ \\
\hline
\end{tabular}

Fig. 2.13 Geographical distribution of the exceedance of the CL function for acidity $\left(\mathrm{CLF}_{\mathrm{aci}}\right)$ and the exceedance risk of eutrophying $\mathrm{N}$ (Ex exceedance, pot.Ex potential exceedance) on NFSI plots in 2006. Potential exceedance was calculated from the conservative approach with $\mathrm{N}_{\text {crit }}=0.2-0.4 \mathrm{mg}^{-1} \mathrm{~N}$

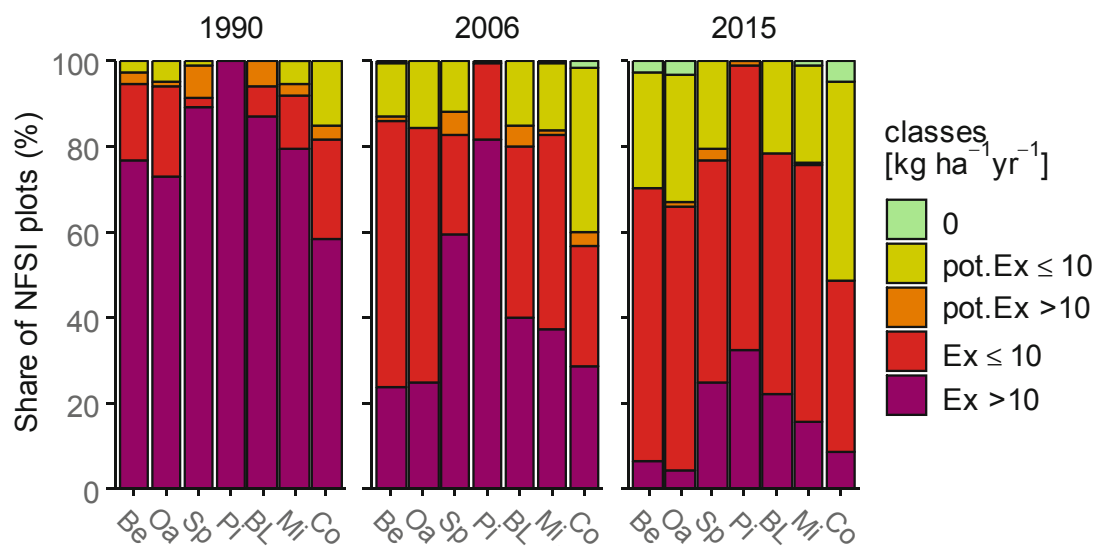

Fig. 2.14 Relative frequency of exceedance risk of eutrophying $\mathrm{N}$ (Ex exceedance, pot.Ex potential exceedance) on NFSI plots in 1990, 2006 and 2015 on different forest stand types (Fig. 2.10). Potential exceedance is calculated from the conservative approach with $\mathrm{N}_{\text {crit }}=0.2-0.4 \mathrm{mg}^{-1} \mathrm{~N}$ 


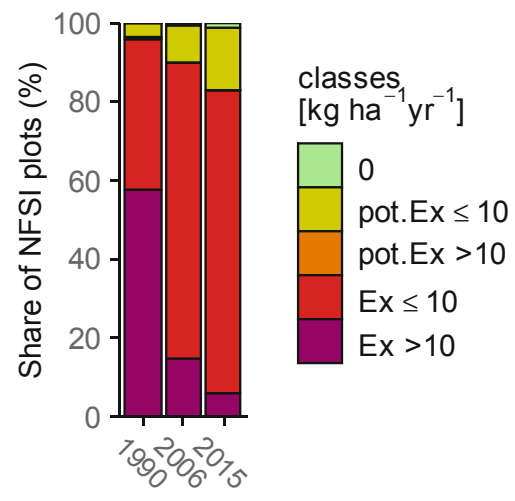

Fig. 2.15 Relative frequency of exceedance risk of the CL function for acidification and eutrophication for two pollutants (Ex, exceedance; pot.Ex, potential exceedance) on NFSI plots in 1990, 2006 and 2015. Potential exceedance is calculated from the conservative approach with $\mathrm{N}_{\text {crit }}=0.2-0.4 \mathrm{mg}^{-1} \mathrm{~N}$. Not visible are negligible shares of the classes "0" (1990: 0.06, 2006: 0.23 ) and "pot.Ex > 10" (1990: 0.51, 2006: 0.17, 2015: 0.06)

without risk of exceedance) in 2006. Exceedances $>10 \mathrm{~kg} \mathrm{ha}^{-1}$ year $^{-1}$ occurred on $24-28 \%$ of the beech, oak and other coniferous stands and on $37-59 \%$ of the mixed, other broadleaf and spruce stands in 2006 (Fig. 2.14). In 2015, extreme exceedances of $\mathrm{CL}_{\text {nut }}(\mathrm{N})$ were further reduced, while most of the NFSI plots were still exposed to moderate or at least potential exceedance.

The integrated evaluation of critical loads exceedances of acidifying and eutrophying depositions (CLRTAP 2015) showed that, despite the reduction of S and $\mathrm{NO}_{x}$ emissions, $90 \%$ of the NFSI plots were still compromised in 2006 and only $0.2 \%$ were beyond the risk of exceedance (Fig. 2.15).

Exposure types (Gauger et al. 2008) classify the plots according to the need for deposition reductions (Fig. 2.16). The sole reduction of S deposition at constant $\mathrm{N}$ deposition rates would result in non-exceedance of the CL function on only a minimal share of the NFSI plots (1\% in 1990 and $2 \%$ in 2006). From 1990 to 2006, only the share of plots with need for reduction of $\mathrm{S}$ deposition (at additional need for reduction of $\mathrm{N}$ deposition) was reduced substantially (from 35 to $18 \%$ ), while the share of plots with need for reduction of $\mathrm{N}$ input remained at an alarmingly high level (95\% in 1990 and $88 \%$ in 2006) (Fig. 2.16). This trend continued until 2015.

\subsection{Summary and Conclusions}

The spatial variability of environmental impact factor like climate or tree species distribution or soil class in Germany is high. That leads to small-scale pattern of characteristics of forest soils. Forest policy like liming is under the responsibility of the federal states; that is why impact factors change at borders of different federal 


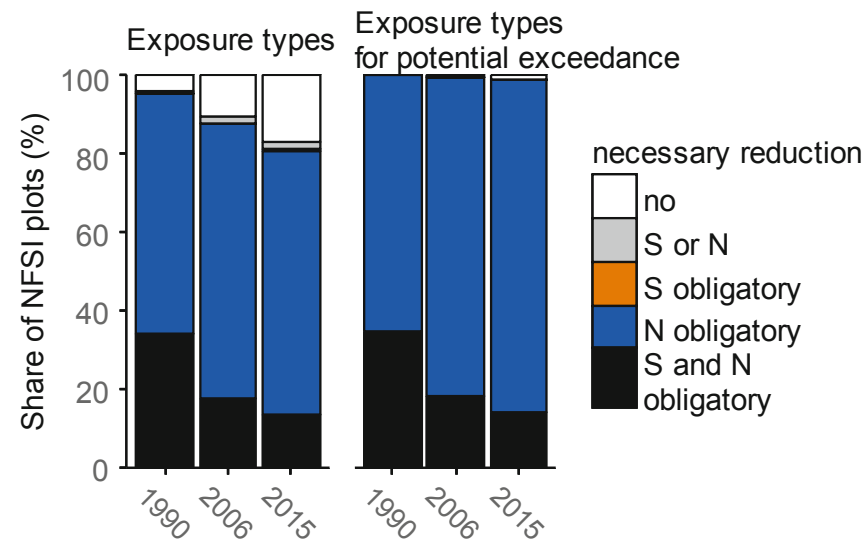

Fig. 2.16 Relative frequency of exposure types for exceedance and for potential exceedance (calculated from the conservative approach) of the CL function for two pollutants on NFSI plots in 1990, 2006 and 2015. Not visible are negligible shares of exposure types of the classes "S or N" (1990: 0.06) and "S obligatory" (1990: 0.34, 2006: 0.28, 2015: 0.40) and exposure types for potential exceedance of the classes "no" (1990: 0.06, 2006: 0.23, 2015: 1.02), "S or N" (2006: 0.11, 2015: 0.06) and "S obligatory" (2015: 0.06)

states. Furthermore many important impact factor changes within the NFSI. The exposure to airborne pollutants decreased in the interval between the first and the second inventory. The situation improved mainly for acidifying $\mathrm{S}$ depositions and for extreme exceedances of eutrophying $\mathrm{N}$ input. However, more than one third of the investigated plots were still exposed to critical rates of acidifying depositions and almost all plots to critical rates of eutrophying $\mathrm{N}$ prior to the second inventory. The contribution of $\mathrm{N}$ to acidification increased, and these trends continued since the second NFSI. That leads to small-scale pattern of characteristics of forest soils which were investigated in the following chapters.

\section{References}

Ad-HocAG_Boden (ed) (2005) Bodenkundliche Kartieranleitung (KA 5), vol 5. Schweizerbart'sche Verlagsbuchhandlung, Stuttgart

AK Standortskartierung (2003) Forstliche Standortsaufnahme: Begriffe, Definitionen, Einteilungen, Kennzeichnungen, Erläuterungen, 6th edn. IHW-Verlag, Eiching near Munich

ARGE_StickstoffBW (ed) (2014) Ermittlung standortspezifischer Critical Loads für Stickstoff Dokumentation der Critical Limits und sonstiger Annahmen zur Berechnung der Critical Loads für bundesdeutsche FFH-Gebiete, vol ID Umweltbeobachtung U26-S7-N12. Arbeitsgemeinschaft Stickstoff, federal state Baden-Württemberg, Karlsruhe

Augusto L, Ranger J, Binkley D, Rothe A (2002) Impact of several common tree species of European temperate forests on soil fertility. Ann For Sci 59(3):233-253. https://doi.org/10. 1051/forest:2002020 
Balla S, Müller-Pfannenstiel K, Uhl R, Kiebel A, Lüttmann J, Lorentz H, Düring I, Schlutow A, Schleuschner T, Förster M, Becker C, Herzog W (2013) Untersuchung und Bewertung von straßenverkehrsbedingten Nährstoffeinträgen in empfindliche Biotope. Forschung Straßenbau und Straßenverkehrstechnik, vol 1099. Federal Highway Research Institute (BASt), Bremen

BMEL (2014) Der Wald in Deutschland - Ausgewählte Ergebnisse der dritten Bundeswaldinventur. Bundesministerium für Ernährung und Landwirtschaft, Berlin, $54 \mathrm{p}$

Bobbink R, Hettelingh J-P (2011) Review and revision of empirical critical loads and dose-response relationships. Review and revision of empirical critical loads and dose-response relationships. National Institute for Public Health and the Environment (RIVM), Noordwijkerhout

Bucher JB (1984) Bemerkungen zum Waldsterben und Umweltschutz in der Schweiz. Forstwissenschaftliches Centralblatt 103(1):16-27

Bytnerowicz A, Omasa K, Paoletti E (2007) Integrated effects of air pollution and climate change on forests: a northern hemisphere perspective. Environ Pollut 147(3):438-445. https://doi.org/ 10.1016/j.envpol.2006.08.028

CLRTAP (2015) Exceedance calculations. In: Manual on methodologies and criteria for modelling and mapping critical loads and levels and air pollution effects, risks and trends. UNECE Convention on Long-range Transboundary Air Pollution. http://www.icpmapping.org/. Accessed 1 Dec 2018

de Vries W, Dobbertin MH, Solberg S, Van Dobben HF, Schaub M (2014) Impacts of acid deposition, ozone exposure and weather conditions on forest ecosystems in Europe: an overview. Plant Soil 380(1-2):1-45

Eichhorn J, Icke R, Isenberg A, Paar U, Schönfelder E (2005) Temporal development of crown condition of beech and oak as a response variable for integrated evaluations. Eur J For Res 124 (4):335-347. https://doi.org/10.1007/s10342-005-0097-z

Ellenberg H (1971) Integrated experimental ecology: methods and results of ecosystem research in the German Solling Project. In: Ecological studies, vol 2. Springer, Berlin

Ellenberg H, Leuschner C (2010) Vegetation Mitteleuropas mit den Alpen: In ökologischer, dynamischer und historischer Sicht, 6th edn. UTB, Stuttgart

Fraley C, Raftery AE, Scrucca L, Murphy TB, Fop M (2017) Mclust: gaussian mixture modelling for model-based clustering, classification, and density estimation, $r$ package version 5.3. https:// cran.r-project.org/web/packages/mclust/index.html

Gauger T, Haenel HD, Rösemann C, Nagel HD, Becker R, Kraft P, Schlutow A, Schütze G, Weigelt-Kirchner R, Anshelm F (2008) Nationale Umsetzung UNECE-Luftreinhaltekonvention (Wirkungen). Teil 2: Wirkungen und Risiokoabschätzungen Critical Loads, Biodiversität, Dynamische Modellierung, Critical Levels Überschreitungen, Materialkorrosion. Im Auftrag des Umweltbundesamtes, Dessau-Rosslau

Härdtle W (1995) Vegetation und Standort der Laubwaldgesellschaften (Querco-Fagetea) im nördlichen Schleswig-Holstein. Mitteilungen der Arbeitsgemeinschaft Geobotanik in Schleswig-Holstein und Hamburg, Kiel

Hartmann P, von Wilpert K (2016) Statistisch definierte Vertikalgradienten der Basensättigung sind geeignete Indikatoren für den Status und die Veränderungen der Bodenversauerung in Waldböden. Allgemeine Forst-und Jagdzeitung 187(3-4):61-69

Hilbrig L, Wellbrock N, Bielefeldt J (2014) Harmonisierte Bestandesinventur: Zweite Bundesweite Bodenzustandserhebung (BZE II) - Methode. Thünen Working Paper. Johann Heinrich von Thünen Institute, Braunschweig. https://doi.org/10.3220/WP_26_2014

Höhle J, Bielefeldt J, Dühnelt P-E, König N, Ziche D, Eickenscheidt N, Grüneberg E, Hilbrig L, Wellbrock N, Kompa T (2018) Bodenzustandserhebung im Wald - Dokumentation und Harmonisierung der Methoden. Thünen Working Paper. Johann Heinrich von Thünen Institute, Braunschweig. https://doi.org/10.3220/WP1526989795000

Kauppi P, Anttila P, Kenttämies K (1990) Acidification in Finland. Finnish Acidification Research Programme HAPRO 1985-1990. Springer, Berlin 
Kölling C, Hoffmann M, Gulder H-J (1996) Bodenchemische Vertikalgradienten als charakteristische Zustandsgrößen von Waldökosystemen. Z Pflanzenernähr Bodenkd 159 (1):69-77. https://doi.org/10.1002/jpln.1996.3581590111

Kreutzer K (1972) Über den Einfluß der Streunutzung auf den Stickstoffhaushalt von Kiefernbeständen (Pinus sylvestris L.). Forstwissenschaftliches Centralblatt 91(1):263-270

Ludemann T (2002) Historische Holznutzung und Waldstandorte im Südschwarzwald. Freiburger Forstliche Forschung 18:194-207

Lüst C, Giani L (2006) Merkmale von Böden unter rezenten Wäldern, die auf ehemals landwirtschaftlich genutzten Flächen stocken. Drosera 1(2):27-34

Manion PD (1981) Tree disease concepts. Prentice-Hall, Englewood Cliffs, NJ

Nihlgård B (1985) The ammonium hypothesis: an additional explanation to the forest dieback in Europe. Ambio 14(1):2-8

Nilsson J, Grennfelt P (1988) Critical loads for sulphur and nitrogen. Workshop on "Critical Loads for the effect on soils and groundwater of long term deposition of nitrogen and sulphur compounds and to establish methods to map the geographical areas experiencing higher than critical loads with respect to the sensitivity of different soil types". UN-ECE - Nordic Council of Ministers, Skokloster

Peters M (1990) Nutzungseinfluß auf die Stoffdynamik schleswig-holsteinischer Böden: Wasser-, Luft-, Nähr-und Schadstoffdynamik. Kiel University, Kiel

Pretzsch H, Block J, Dieler J, Dong PH, Kohnle U, Nagel J, Spellmann H, Zingg A (2010) Comparison between the productivity of pure and mixed stands of Norway spruce and European beech along an ecological gradient. Ann For Sci 67(7):712. https://doi.org/10.1051/ forest $/ 2010037$

R Core Team (2017) R: a language and environment for statistical computing. R Foundation for Statistical Computing, Vienna

Rinklebe J, Makeschin F (2003) The impact of arable and forest land use on soil and vegetation - a comparison after 27 years. Forstwissenschaftliches Centralblatt 122(2):81-98. https://doi.org/ 10.1046/j.1439-0337.2003.00081.x

Schöpp W, Posch M, Mylona S, Johansson M (2003) Long-term development of acid deposition (1880-2030) in sensitive freshwater regions in Europe. Hydrol Earth Syst Sci 7(4):436-446

Schütt P, Blaschke H, Holdenrieder O, Koch W, Lang KJ, Schuck HJ, Stimm B, Summerer H (1984) Der Wald stirbt an Stress. Bertelsmann, Munich

Ulrich B (1983) Soil acidity and its relations to acid deposition. In: Ulrich B, Pankrath J (eds) Effects of accumulation of air pollutants in forest ecosystems. Springer, Dordrecht, pp 127-146

Ulrich B (1986) Die Rolle der Bodenversauerung beim Waldsterben: Langfristige Konsequenzen und forstliche Möglichkeiten. Forstwissenschaftliches Centralblatt 105(1):421-435

Ulrich B (1987) Stability, elasticity, and resilience of terrestrial ecosystems with respect to matter balance. In: Schulze E-D, Zwölfer H (eds) Potentials and limitations of ecosystem analysis. Ecological studies 61. Springer, Berlin, pp 11-49

Ulrich B (1995) The history and possible causes of forest decline in central Europe, with particular attention to the German situation. Environ Rev 3(3-4):262-276

UNECE (1979) Convention on Long-range Transboundary Air Pollution (CLRTAP). United Nations Economic Commission for Europe, Geneva

Verstraeten A, Neirynck J, Genouw G, Cools N, Roskams P, Hens M (2012) Impact of declining atmospheric deposition on forest soil solution chemistry in Flanders, Belgium. Atmos Environ 62:50-63. https://doi.org/10.1016/j.atmosenv.2012.08.017

von Wilpert K (1996) Aus der BZE abgeleitete Indizien einer bodenchemischen Drift in BadenWürttemberg. Mitteilungen der Deutschen Bodenkundlichen Gesellschaft 79:189-192

Waldner P, Marchetto A, Thimonier A, Schmitt M, Rogora M, Granke O, Mues V, Hansen K, Karlsson GP, Zlindra D, Clarke N, Verstraeten A, Lazdins A, Schimming C, Iacoban C, Lindroos AJ, Vanguelova E, Benham S, Meesenburg H, Nicolas M, Kowalska A, Apuhtin V, Napa U, Lachmanova Z, Kristoefel F, Bleeker A, Ingerslev M, Vesterdal L, Molina J, Fischer U, Seidling W, Jonard M, O'Dea P, Johnson J, Fischer R, Lorenz M (2014) Detection of temporal 
trends in atmospheric deposition of inorganic nitrogen and sulphate to forests in Europe. Atmos Environ 95:363-374. https://doi.org/10.1016/j.atmosenv.2014.06.054

Waldner P, Thimonier A, Pannatier EG, Etzold S, Schmitt M, Marchetto A, Rautio P, Derome K, Nieminen TM, Nevalainen S, Lindroos AJ, Merila P, Kindermann G, Neumann M, Cools N, de Vos B, Roskams P, Verstraeten A, Hansen K, Karlsson GP, Dietrich HP, Raspe S, Fischer R, Lorenz M, Iost S, Granke O, Sanders TGM, Michel A, Nagel HD, Scheuschner T, Simoncic P, von Wilpert K, Meesenburg H, Fleck S, Benham S, Vanguelova E, Clarke N, Ingerslev M, Vesterdal L, Gundersen P, Stupak I, Jonard M, Potocic N, Minaya M (2015) Exceedance of critical loads and of critical limits impacts tree nutrition across Europe. Ann For Sci 72 (7):929-939. https://doi.org/10.1007/s13595-015-0489-2

Wentzel KF (1979) Schwefel-Immissionsbelastung der Koniferenwalder des Raumes Frankfurt/ Main. Forstarchiv 50(6):112-121

Wentzel KF (1982) Immissionen oder Saurer Regen - Wovon sterben Wälder und Seen. Der Forstund Holzwirt 37:410-413

Wittich W (1951) Der Einfluß der Streunutzung auf den Boden. Forstwissenschaftliches Centralblatt 70(2):65-92

Wolff B, Riek W (1996) Deutscher Waldbodenbericht 1996 - Ergebnisse der bundesweiten Bodenzustandserhebung im Wald von 1987-1993. Bundesministerium für Ernährung, Landwirtschaft und Forsten, Bonn

Wolff B, Erhard M, Holzhausen M, Kuhlow T (2003) Das Klima in den forstlichen Wuchsgebieten und Wuchsbezirken Deutschlands. Mitteilungen der Bundesforschungsanstalt für Forst-und Holzwirtschaft, vol 211. Kommissionsverlag Max Wiedenbusch, Hamburg

Ziche D, Seidling W (2010) Homogenisation of climate time series from ICP Forests Level II monitoring sites in Germany based on interpolated climate data. Ann For Sci 67(8):804. https:// doi.org/10.1051/forest/2010051

Open Access This chapter is licensed under the terms of the Creative Commons Attribution 4.0 International License (http://creativecommons.org/licenses/by/4.0/), which permits use, sharing, adaptation, distribution and reproduction in any medium or format, as long as you give appropriate credit to the original author(s) and the source, provide a link to the Creative Commons licence and indicate if changes were made.

The images or other third party material in this chapter are included in the chapter's Creative Commons licence, unless indicated otherwise in a credit line to the material. If material is not included in the chapter's Creative Commons licence and your intended use is not permitted by statutory regulation or exceeds the permitted use, you will need to obtain permission directly from the copyright holder.

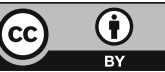

